\title{
PENERAPAN RATIONAL EMOTIVE BEHAVIOR THERAPY (REBT) UNTUK MENINGKATKAN PSYCHOLOGICAL WELL-BEING PADA PENDERITA EPILEPSI GRANDMAL
}

\author{
Mutiara Mirah Yunita \\ Program Studi Psikologi Universitas Bunda Mulia \\ Mutiara.mirah@gmail.com
}

\begin{abstract}
Epilepsy is the physical illness in many years that have biological, psychological, sociological and spiritual aspect that have impact in individual quality life. Future of patient with epilepsy illness is being determined from psychological condition, in particular in psychological well-being conditions. Patient with epilepsy grandmal often have emotional disorder. They can not accept her or himself, high anxiety, break down feeling, depression, helpless feeling, shame feeling, sadness, dependent, not confident, and defendant feeling, so that emotion negative was have difficult to grow up in self-actualization. The psychology well-being is condition who someone have accept her or himself, accept the past memories, grow up, have a meaning life, positive relation with people, have capacity of managing self, confident to deciding whatever something best. Enhancement of psychology well-being is being done by rational emotive behaviour therapy (REBT) which is a technique to straighten irrationally minded that create emotionally disorder. This research use qualitative (in-depth interview, observation) and psychological test. Besides that, questionnaire, pre-test, and post-test. Subject in this research is woman, 21 years old who has epilepsy grandmal illness in the low psychological well-being condition. She has average IQ and emotional disorder. The intervention is being done in tenth. According result by questionnaire data, the intervention has be done is positive result. It has enhancement of psychological well-being for subject who epilepsy grandmal. Those are changes behaviour that expected in subject.
\end{abstract}

Keywords : psychological well-being; grandmal epilepsy; rational emotive behavior therapy

\begin{abstract}
ABSTRAK
Epilepsi merupakan sebuah penyakit fisik yang memiliki aspek secara biologis, psikologis, sosiologis dan kehidupan spiritual yang berdampak kuat terhadap kesejahteraan kehidupan penderitanya. Masa depan individu dengan epilepsi ditentukan oleh kondisi psikologis, termasuk dalam psychological well-being. Pasien dengan epilepsi grandmal biasanya memiliki gangguan emosional seperti tidak menerima diri sendiri, kecemasan yang tinggi, perasaan rendah diri, depresi, ketidakmampuan menolong diri sendiri, perasaan malu dan sedih, kebergantungan, tidak percaya diri, dan perasaan bersalah yang besar. Tentu saja seluruh emosi negatif ini menghalangi pertumbuhan dan aktualisasi dirinya. Psychological wellbeing merupakan kondisi seseorang dapat menerima kondisi dirinya atau keadaan masa lalu, menemukan makna dan tujuan dalam hidupnya, memiliki relasi sosial yang positif, memiliki kapasitas untuk memenejemen diri, percaya bahwa segala sesuatu dapat dicapai dengan baik. Meningkatkan psychological well-being dapat dilakukan dengan teknik terapi rational emotive behaviour therapy $(R E B T)$ yang merupakan teknik untuk meluruskan pikiran yang irasional terhadap sebuah kejadian yang menyebabkan gangguan emosional yang berakibat orang dengan epilepsi menjadi kolaps. Penelitian ini menggunakan metode kualitatif (wawancara mendalam dan obervasi terstruktur) serta diperlengkapi dengan psikotes. Selain itu, juga menggunakan kuesioner, pre-test dan post-test. Subjek dalam penelitian ini adalah wanita berusia 21 tahun yang menderita epilepsi grandmal, yang memiliki kondisi psychological well-being yang rendah. Subjek memiliki IQ rata-rata cerdas dan memiliki masalah emosional dan kecemasan. Berdasarkan hasil dari data kuesioner dan hasil data yang dianalisis, intervensi memiliki hasil yang positif terhadap perilaku yang diharapkan.
\end{abstract}

Kata kunci : psychological well-being; epilepsi grandmal; rational emotive behavior therapy 


\section{PENDAHULUAN}

\subsection{Latar Belakang}

Epilepsi adalah salah satu penyakit neurologi menahun yang dapat mengenai siapa saja di dunia tanpa batasan usia, gender, ras, sosial, dan ekonomi. Di Indonesia, epilepsi dikenal oleh masyarakat sebagai "ayan" atau "sawan". Epilepsi berasal dari bahasa Yunani, Epilambanmein yang berarti serangan. Epilepsi adalah kelainan di otak yang ditandai oleh aktifitas otak yang terlampau tinggi yang tidak dapat dikawal (Guyton dan Hall, dalam Hantoro, 2013). Sedangkan menurut Edward dan Bouchier (2002) berpendapat bahwa epilepsi merupakan manisfestasi gangguan fungsi otak dengan berbagai penyebab (etiologi), namun dengan gejala tunggal yang khas, yakni serangan berkala yang disebabkan oleh lepasnya muatan listrik pada neuronneuron otak secara berlebihan dan paroksimal. Ada dua jenis epilepsi, yaitu Epilepsi Umum dan Epilepsi Parsial. Beberapa jenis Epilepsi Umum adalah Epilepsi Petit Mal, Epilepsi Grandmal, Epilepsi Myoklonik Juvenil. Kemudian epilepsi yang tergolong Parsial adalah Epilepsi Parsial Sederhana dan Epilepsi Parsial Kompleks. Dalam penelitian ini menggunakan epilepsi jenis Grandmal. Epilepsi Grandmal adalah epilepsi yang terjadi secara mendadak, di mana penderitanya hilang kesadaran lalu kejang-kejang dengan napas berbunyi ngorok dan mengeluarkan buih/busa dari mulut.

Di Indonesia telah didirikan sebuah Yayasan Epilepsi Indonesia (YEI) yang dipimpin oleh dr. Irawaty Hawari, SpS, pada tanggal 8 Oktober 1992, dengan maksud dan tujuan membantu meningkatkan upaya-upaya penanggulangan Epilepsi di Indonesia dengan usaha-usaha terutama pada aspek psikososial (Kangeaningsih, 2013).

Dewasa ini, epilepsi sudah dapat didiagnosis dengan tepat karena ada perangkat penunjang yang lebih baik selain anamnesis klinis. Akan tetapi untuk penatalaksanaannya perlu dipikirkan secara menyeluruh dan terintegrasi karena epilepsi mempunyai aspek bio-psiko-sosio-spiritual yang berdampak dengan kualitas hidup orang dengan epilepsi. Masa depan penderita epilepsi harus ditinjau dari berbagai segi dan bukan hanya dari kambuh tidaknya serangan, melinkan juga dari kondisi psikologisnya seperti kemampuan mental, tingkat pendidikan yang dicapai, budi pekerti, tingkah laku juga ikut mempengaruhi masa depan penderita. Khususnya dengan kondisi psychological well-being yang dimiliki oleh masing-masing individu yang menderita epilepsi.

Menurut Ryff (1989) psychological well-being merupakan sebuah kondisi di mana individu memiliki sikap yang positif terhadap diri sendiri dan orang lain, dapat membuat keputusan sendiri dan mengatur lingkungan yang kompatibel dengan kebutuhannya, memiliki tujuan hidup dan membuat hidup mereka lebih bermakna serta berusaha mengeksplorasi dan mengembangkan dirinya. Akan tetapi, tidak semua penderita epilepsi memiliki kesadaran diri mengenai kondisi psychological well-being dalam menjalani kehidupannya, terutama dalam menghadapi tekanan dari lingkungan yang menyebabkan terjadinya distress dan kambuhnya serangan epilepsi.

Lumbantobing (1994) mengatakan ada penderita epilepsi sifatnya agresif, mudah tersinggung, sering sedih, keras kepala, hiperaktif, tidak tenang, sering suka berbohong, mencuri, berkelahi, kelainan seksual, kejam dan suka merusak, tetapi banyak pula penderita epilepsi yang tidak berkelakuan demikian. Banyak juga penderita epilepsi yang berkepribadian "normal". Seperti yang dikemukakan oleh Edward dan Bouchier (2002) menyatakan bahwa tidak ada perbedaan kepribadian penderita epilepsi dengan seorang yang tidak mengidap epilepsi (normal). Akan tetapi, ada beberapa faktor pencetus yang menyebabkan peningkatan frekuensi timbulnya bangkitan epilepsi, salah satunya adalah kondisi emosi yang negatif. Selain itu, kurangnya waktu tidur, kelelahan fisik dan mental, lupa minum obat, penggunaan obatobat terlarang dan alkohol, mencetuskan kondisi psychological well-being penderita epilepsi semakin rendah. Padahal menurut Lumbantobing (1994) mengatakan bahwa serangan epilepsi semaksimalnya harus dapat dicegah karena serangan epilepsi mengakibatkan kerugian pada penderitanya. Oleh karena itu, kondisi psikologis merupakan salah satu faktor yang dapat mempengaruhi serangan epilepsi tersebut.

Pada penderita epilepsi yang "kalah" kemudian menunjukkan berbagai tingkah laku maladaptif. Edward dan Bouchier (2002) menyatakan bahwa masalah perilaku khusus pada penderita epilepsi sangat mungkin terjadi akibat tingginya frekuensi bangkitan. 
Sedangkan frekuensi bangkitan terjadi apabila penderita epilepsi mengalami distres. Hal inilah yang ingin dibahas oleh penulis di dalam melakukan penelitian ini. Bahwa terlepas dari epileptic personality, seorang penderita epilepsi akan lebih sering terkena serangan tatkala ia memiliki kondisi psychological well-being yang rendah, yang berdampak pula pada kualitas kehidupan yang rendah.

Kematangan kondisi psikologis individu tentunya bergantung pada faktor lingkungan, pola asuh dan tingkat pendidikan selama masa perkembangan. Seorang individu dengan epilepsi tentunya sering mendapatkan perlakuan yang berbeda dari saudarasaudaranya. Mungkin penderita terlalu dilindungi (over-protected) oleh orang tuanya. Mungkin pula ia seolah disingkirkan (rejected) dalam kehidupan keluarga. Banyak juga penderita epilepsi yang tidak diterima dalam lingkungan pergaulannya. Kondisi-kondisi ini menyebabkan terhambatnya pertumbuhan psychological well-being seseorang sehingga kurang realistis dalam menghadapi masalah hidup dan kenyataan, yang seringkali menimbulkan terjadinya distres. Manisfestasi dari kondisi psychological well-being yang rendah pada penderita epilepsi biasanya adalah mudah merasa cemas, rendah diri, mudah depresi, perasaan tidak berdaya, malu, sedih, merasa bersalah, iri hati, dan kurang mandiri. Oleh sebab itu, pentingnya untuk meningkatkan kondisi psychological wellbeing pada penderita epilepsi, agar para penderita epilepsi dapat memiliki kesejahteraan hidup terutama dalam mengelola distres agar dapat bertumbuh secara psikologis ke level yang lebih tinggi, sehingga penderita epilepsi menjadi semakin cerdas dan mampu dalam menghadapi tantangan ketika ingin memenuhi kebutuhannya. Hal ini didukung oleh pendapat dari Lumbantobing (1994) yang mengatakan bahwa keadaan yang dapat mencetuskan terjadinya serangan epilepsi, salah satunya adalah gangguan emosional (distres).

Telah lama diketahui bahwa gangguan emosional dapat memperbanyak atau meningkatkan jumlah serangan epilepsi. Keadaan frustasi, tegang, cemas, takut, semua hal ini dapat mencetuskan serangan epilepsi. Keadaan sedemikian sering dijumpai pada penderita epilepsi yang remaja atau dewasa muda. Gangguan emosional dapat meningkatkan frekuensi semua jenis epilepsi. Keadaan ini membuat seorang penderita epilepsi terkesan seolah tidak memiliki kemampuan untuk mengelola distres dan tekanan emosional yang berasal dari lingkungannya. Akan tetapi kondisi ini tergantung pada jenis epilepsi yang diderita dan kepribadian si penderita epilepsi.

Peningkatan psychological well-being bertujuan agar penderita epilepsi memiliki kemampuan untuk mengatasi dan beradaptasi terhadap kejadian yang berat atau masalah yang terjadi dalam kehidupannya, serta mampu mengelola stres dan memonitor dirinya sendiri. Kondisi psychological wellbeing yang dimiliki oleh individu dapat berubah melalui cara berpikir yang realibel dan valid sehingga dapat mencapai suatu perubahan perilaku yang mensejahterakan diri sendiri dan lingkungannya.

Penelitian ini berfokus pada pengembangan psychological well-being penderita epilepsi jenis grandmal yang sedang menjalani pengobatan. Enam dimensi psyhological well-being yang merupakan intisari dari teori-teori positive functioning psychology yang dirumuskan oleh Ryff (dalam Ryff, 1989 ; Ryff dan Keyes, 1995), yaitu : dimensi penerimaan diri, dimensi hubungan yang positif dengan orang lain, dimensi otonomi, dimensi penguasaan lingkungan, dimensi tujuan hidup, dan dimensi pertumbuhan pribadi. Faktor-faktor dalam psychological well-being ini dapat memberikan kekuatan bagi penderita epilepsi untuk memperkecil serangan epilepsi sehingga mengurangi risiko rusaknya sel-sel di dalam otak dan dampak negatif secara psikologis seperti perasaan bersalah atau rasa malu. Selain itu, dapat juga meningkatkan kemampuan mengelola stres dan meningkatkan kesejahteraan psikologis.

Kondisi psychological well-being yang dimiliki penderita epilepsi mampu mendorong proses penyesuaian diri yang baik meskipun mereka berada pada kondisi pengobatan. Terutama pada penderita epilepsi dengan kepribadian yang dependen. Psycological well-being perlu ditingkatan pada diri penderita epilepsi terutama dengan ciri kepribadian dependen sebab ketidakmampuannya dalam menghadapi tanggung jawab menyebabkan tekanan emosional dan mood yang menyebabkan distres, yang menjadi penyebab utama yang 
mencetuskan serangan epilepsi. Melalui pendekatan Terapi Perilaku Emotif Rasional (Rational Emotive Behavior Therapy, diharapkan penderita epilepsi grandmal dengan kondisi psychological well-being yang rendah, dapat ditingkatkan.

\subsection{Tujuan Penelitian}

Berdasarkan rumusan masalah di atas maka tujuan dari penelitian ini adalah ingin mengetahui hasil penerapan terapi REBT untuk meningkatkan kondisi psychological well-being pada penderita epilepsi grandmal. Sedangkan manfaat teoritis dari penelitian ini adalah memberikan sumbangan pengetahuan khususnya untuk bidang psikologi klinis tentang penerapan REBT dalam meningkatkan psychological well-being pada penderita epilepsi grandmal. Kemudian manfaat praktis dari penelitian ini adalah memberikan kontribusi secara praktis dalam bidang psikologi agar penderita epilepsi grandmal yang sedang menjalani pengobatan dapat meningkatkan psychological well-being sehingga dapat menjalani fungsi pekerjaannya secara lebih adaptif dapat mengelola stres dengan baik demi membangun masa depannya.

\section{TINJAUAN PUSTAKA 2.1. Epilepsi}

Menurut Kangeaningsih (2013) seseorang disebut menderita epilepsi jika mengalami kejang sebanyak 2 kali atau lebih tanda suatu penyebab yang jelas, dengan interval antara kejang lebih dari 24 jam. Artinya, kejang bukan disebabkan oleh demam tinggi, trauma kepala, radang otak, tumor otak, dan kekurangan gula darah atau elektrolit. Kejang pada epilepsi sebagian besar hanya berlangsung beberapa detik sampai kurang dari 5 menit dan sebagian besar berhenti sendiri. Sebelum dan sesudah serangan kejang aktivitas anak-anak normal-normal saja, bisa dalam keadaan tidur, sedang bermain, belajar atau menonton TV. Setelah kejang seseorang mungkin akan tampak bingung atau capek selama beberapa waktu, setelah itu aktivitas kembali normal. Sering kali penyebab epilepsi tidak dapat ditentukan, 7 dari 10 kasus tidak diketahui penyebabnya, sehingga disebut sebagai idiopatik (bahasa latin : tidak diketahui penyebabnya). Jika penyebab epilepsi diketahui disebut simtomatik. Beberapa keadaan yang dapat menyebabkan epilepsi di kemudian hari adalah : 1). Gangguan perkembangan otak yang dapat terjadi sebelum lahir, ada saat persalinan (anak lahir kurang oksigen), maupun setelah lahir. 2). Keadaankeadaan yang menyebabkan kerusakan jaringan otak, seperti trauma kepala, pendarahan, tumor, infeksi otak (ensefalitis), atau infeksi selaput otak (meningitis). Tidak semua epilepsi disebabkan oleh faktor keturunan, beberapa individu akan mengalami perubahan spontan dalam susunan gennya yang dapat menyebabkan epilepsi. Akan tetapi, penting untuk menanyakan atau menelusuri apakah ada anggota keluarga, baik dari pihak ayah atau ibu yang pernah mengalami kejang/epilepsi karena jika terdapat riwayat kejang/epilepsi dalam keluarga maka risiko seseorang dalam menyandang epilepsi lebih besar dari keluarga yang tidak mempunyai riwayat kejang/epilepsi. (Kangeaningsih, 2013). Selain itu hal-hal yang dapat mencetuskan kekambuhan kejang antara lain lupa minum obat, minum obat tidak teratur, kurang tidur, makan tidak teratur, stres fisik dan emosional, demam, kadar OAE yang rendah dalam darah, cahaya yang berkedipkedip yang dihasilkan computer, TV, video game (pada pasien epilepsi fotosensitif), (Kangeaningsih, 2013). Sedangkan menurut Lumbantobing (1994) mengatakan bahwa pada seorang penderita epilepsi biasanya timbul secara spontan, namun, kadang-kadang serangan dapat dicetuskan oleh keadaan tertentu. Serangan menjadi lebih sering oleh keadaan tertentu.

Epilepsi terbagi menjadi dua jenis, yaitu Epilepsi Umum dan Epilepsi Parsial. Beberapa jenis Epilepsi Umum adalah Epilepsi Petit Mal yaitu epilepsi yang menyebabkan gangguan kesadaran secara tiba-tiba, di mana seseorang menjadi seperti bengong tidak sadar tanpa reaksi apa-apa, dan setelah beberapa saat bisa kembali normal melakukan aktivitas semula. Lalu Epilepsi Grandmal yaitu epilepsi yang terjadi secara mendadak, di mana penderitanya hilang kesadaran lalu kejangkejang dengan napas berbunyi ngorok dan mengeluarkan buih/busa dari mulut. Sedangkan Epilepsi Myoklonik Juvenil yaitu epilepsi yang mengakibatkan terjadinya kontraksi singkat pada satu atau beberapa otot mulai dari yang ringan tidak terlihat sampai yang menyentak hebat seperti jatuh tiba-tiba, melemparkan benda yang dipegang tiba-tiba, dan lain sebagainya. Kemudian epilepsi yang 
tergolong Parsial adalah Epilepsi Parsial Sederhana yaitu epilepsi yang tidak disertai hilang kesadaran dengan gejala kejang-kejang, rasa kesemutan atau rasa kebal di suatu tempat yang berlangsung dalam hitungan menit atau jam. Sedangkan Epilepsi Parsial Kompleks yaitu epilepsi yang disertai gangguan kesadaran yang dimulai dengan gejala parsialis sederhana namun ditambah dengan halusinasi, terganggunya daya ingat, seperti bermimpi, kosong pikiran, dan lain sebagainya. Epilepsi jenis ini bisa menyebabkan penderita melamun, lari tanpa tujuan, berkata-kata sesuatu yang diulang-ulang, dan lain sebagainya (otomatisme). Dalam penelitian ini menggunakan epilepsi jenis Grand Mal yang merupakan salah satu jenis Epilepsi Umum. Berikut ini akan dikemukakan beberapa faktor yang dapat mencetuskan serangan epilepsi, yaitu Gangguan emosional. Gangguan emosional dapat memperbanyak atau meningkatkan jumlah serangan epilepsi. Keadaan frustasi, tegang, cemas, takut, eksitasi yang hebat, semua hal ini dapat mencetuskan serangan epilepsi. Keadaan sedemikian sering dijumpai pada penderita epilepsi yang remaja atau dewasa muda. Gangguan emosional dapat meningkatkan frekuensi semua jenis epilepsi. Harsono (2011 : 121) mengatakan baahwa stres emosional dapat meningkatkan frekuensi serangan. Peningkatan dosis obat bukanlah merupakan pemecahan masalah, karena dapat menimbulkan efek samping obat. Penyandang epilepsi perlu belajar menghadapi stres. Stres fisik yang berat juga dapat menimbulkan serangan.

\section{2..2. Gambaran Psychological Well-Being pada Penderita Epilepsi}

Menurut Kangeaningsih

mengatakan bahwa diagnosis epilepsi mengakibatkan timbulnya perasaan rendah diri, cemas, dan perasaan tidak berdaya. Bahkan ada yang merasa ingin mati karena penyakitnya. Masalah lain adalah timbulnya depresi sebagai efek samping obat atau depresi yang terjadi sebelum, segera setelah, atau di antara serangan kejang. Depresi juga disebabkan rasa takut terus-menerus akan timbulnya kejang. Seorang anak juga bisa depresi karena sadar bahwa dirinya berbeda dengan anak lain dan harus minum obat terus menerus. Pengalaman hidup seseorang sangat penting dalam pembentukan kepribadian seseorang. Khususnya seorang yang menderita epilepsi sejak kecil.

Tindakan proteksi yang berlebihan pada anak dapat mengganggu perkembangan emosi. Jika anak hanya belajar mengenal rasa takut dan terus menerus dibatasi segala aktivitasnya, maka dia akan tumbuh menjadi anak yang tidak mandiri sampai dewasa. Dalam menjalani kehidupannya, seorang penderita epilepsi seringkali mengalami hambatan-hambatan untuk dapat berkembang ke kematangan psikologis dan dalam meraih cita-citanya. Hal ini dikarenakan ada penderita epilepsi yang sifatnya agresif, mudah tersinggung, sering sedih, keras kepala, hiperaktif, tidak tenang, sering suka berbohong, mencuri, berkelahi, kelainan seksual, kejam dan suka merusak, tetapi ada juga penderita epilepsi yang tidak berkelakuan demikian (Lumbantobing, 1995). Sebuah bentuk kepribadian seorang yang menderita epilepsi, dapat menentukan tinggi dan rendahnya kondisi psychological well-being seseorang penderita epilepsi. Penderita epilepsi selalu merasa cemas kalau serangan epilepsinya akan kumat ditambah lagi persepsi masyarakat yang negatif terhadap penyakit epilepsi. Kondisi psychological well-being yang rendah menyebabkan fungsi pekerjaan dan fungsi sosial seorang penderita epilepsi menjadi terhambat. Hal ini dikarenakan psychological well-being yang rendah juga menyebabkan seseorang kurang dapat mengelola distres dari lingkungan, terutama individu dengan epilepsi sehingga mencetuskan serangan epilepsi yang berkala. Tekanan distres dan terlalu lama berkonsentrasi dapat menyebabkan serangan kembali epilepsi. Menurut Ryff (dalam Dwipayama, 2010) berpendapat bahwa psychological well-being adalah suatu kondisi seseorang yang memiliki kemampuan menerima diri sendiri maupun kehidupannya di masa lalu (self-acceptance), pengembangan atau perrtumbuhan diri (personal growth), keyakinan bahwa hidupnya bermakna dan memiliki tujuan (purpose in life), memiliki kualitas hubungan positif dengan orang lain (positive relationship with other), kapasitas untuk mengatur kehidupan dan lingkungan secara efektif (environmental mastery), dan kemampuan untuk menentukan tindakan sendiri (autonomy). Ryff (1986) merumuskan teori psychological well-being pada konsep kriteria kesehatan mental yang positif. 
Deskripsi orang yang memiliki psychological well-being yang baik adalah orang yang mampu merealisasikan potensi dirinya secara kontinu, maupun menerima diri apa adanya, mampu membentuk hubungan yang hangat dengan orang lain, memiliki kemandirian terhadap tekanan sosial, memiliki arti hidup, serta mampu mengontrol lingkungan eksternal.

\subsection{Teknik-teknik terapi REBT (Rational Emotive Behavior Therapy) \\ REBT adalah sebuah sistim} psikoterapi yang mengajari individu bagaimana sistim keyakinan menentukan yang dirasakan dan dilakukan pada berbagai peristiwa dalam kehidupan (Neenan, dalam Palmer, 2011). Sedangkan menurut Corey (1999) REBT adalah aliran psikoterapi yang berlandaskan asumsi bahwa manusia dilahirkan dengan potensi, baik untuk berfikir rasional dan jujur maupun berfikir irasional dan jahat.

Albert Ellis (dalam Gunarsa, 2003) memiliki pandangan terhadap konsep manusia seperti berikut :

a. Manusia mengkondisikan diri sendiri terhadap munculnya perasaan yang mengganggu pribadinya

b. Kecenderungan biologisnya sama halnya dengan kecenderungan kultural untuk berfikir salah dan tidak ada gunanya, berakibat mengecewakan diri sendiri.

c. Kemanusiaannya yang unik untuk menemukan dan menciptakan keyakinan yang salah, yang mengganggu, sama halnya dengan kecenderungan mengecewakan dirinya sendiri karena gangguan-gangguannya.

d. Kemampuannya luar biasa untuk mengubah proses-proses kognitif, emosi, perilaku, memungkinkan dapat :

1. Memilih reaksi yang berbeda dengan biasanya dilakukan.

2. Menolak mengecewakan diri sendiri terhadap hampir semua hal yang mungkin terjadi.

3. Melatih diri sendiri agar secara setengah otomatis mempertahankan gangguan sedikit mungkin sepanjang hidupnya.

Menurut Corey (1999) manusia umumnya memiliki kecenderungan untuk memelihara diri, berbahagia, berfikir dan mengatakan, mencintai, bergabung dengan orang lain serta tumbuh dan mengaktualisasikan diri. Akan tetapi manusia juga memiliki kecenderungan ke arah menghancurkan diri, menghindari pemikiran, berlambat-lambat, menyesali kesalahan yang tidak berkesudahan, takhayul, intoleransi, perfeksionime, dan mencela diri sendiri. Manusia cenderung terpaku pada pola-pola tingkah laku lama yang disfungsional. Padahal menurut pandangan REBT, manusia memiliki sumber yang tidak terhingga bagi aktualisasi potensi dirinya dan bisa mengubah ketentuan pribadi dan masyarakat.

Pendekatan REBT menganggap bahwa manusia pada hakikatnya adalah korban dari pola pikirnya sendiri yang tidak rasional dan tidak benar, oleh karena itu terapis berusaha untuk memperbaiki melalui pola berpikirnya dan menghilangkan pola berpikir yang tidak rasional. REBT menitikberatkan pada proses berpikir, menilai, memutuskan, menganalisis, dan bertindak.

Ellis (dalam Forggat, 2005) merekomendasikan suatu pendekatan dari teknik REBT, namun dalam penelitian diantaranya :

a. Teknik Kognitif

1). Rational Analysis, analisis peristiwa yang spesifik untuk mengajarkan klien bagaimana cara membuka dan memperdebatkan keyakinan yang tidak rasional yang biasa digunakan pada sesi pertama dan setelah klien mendapatkan idenya maka membawanya sebagai pekerjaan rumah. Strategi yang paling penting dalam REBT adalah pekerjaan rumah, kegiatan yang termasuk di dalamnya adalah aktivitas membaca, latihan menolong diri sendiri, menulis dan pengalaman aktivitas. Sesi-sesi dalam terapi adalah sesi-sesi latihan, di mana klien mencoba menggunakan apa yang sudah dipelajari.

2). Double-standart dipute, bila klien merasa rendah diri terhadap perilakunya, tanyakan apakah mereka akan segera menilai orang lain (seperti teman baik atau terapis) dalam melakukan hal yang sama atau merekomendasikan orang lain untuk berpengangan pada keyakinan utamanya.

b. Teknik Perilaku

1). Risk Taking, tujuannya adalah untuk menantang keyakinan yang menimbulkan perilaku yang beresiko dan membahayakan, 
ketika alasan yang dikatakan dari hasil tidak ada garansinya maka mereka memiliki kesempatan yang berharga. Sebagai contoh seseorang yang takut akan ditolak malah mencoba untuk mengajak berkencan.

c. Teknik Imajeri

1). Time Projection, teknik ini didesain untuk menunjukkan bahwa kehidupan seseorang dan dunia secara umum akan terus berlanjut setelah rasa takut dan kejadian yang tidak diinginkan akan datang dan pergi, meminta klien untuk melihat kejadian yang tidak diinginkan itu terjadi dan bayangkan kejadian tersebut berjalan terus dalam seminggu, sebulan, enam bulan, setahun, dan seterusnya. Pertimbangkan bagaimana perasaan klien untuk setiap waktu yang dilewati. Klien akan mampu melihat bahwa hidup akan terus berjalan meskipun mereka membutuhkan penyesuain diri untuk kita.

Adapun skema paradigma sebagai kerangka berpikir :

Tabel 1 : Desain A - B - A

\begin{tabular}{|c|c|c|}
\hline $\begin{array}{l}\text { Sasaran } \\
\text { Perilaku }\end{array}$ & $\begin{array}{l}\text { Teknik } \\
\text { REBT }\end{array}$ & $\begin{array}{l}\text { Perilaku } \\
\text { yang } \\
\text { Diharapkan }\end{array}$ \\
\hline Cemas & $\begin{array}{l}\text { Rational } \\
\text { analysis }\end{array}$ & Ceria \\
\hline $\begin{array}{l}\text { Merasa } \\
\text { rendah diri }\end{array}$ & $\begin{array}{l}\text { Double } \\
\text { standard } \\
\text { dispute }\end{array}$ & $\begin{array}{l}\text { Merasa } \\
\text { percaya diri }\end{array}$ \\
\hline $\begin{array}{l}\text { Mudah } \\
\text { depresi }\end{array}$ & $\begin{array}{l}\text { Rational } \\
\text { analysis }\end{array}$ & Gembira \\
\hline $\begin{array}{l}\text { Perasaan } \\
\text { tidak berdaya }\end{array}$ & Risk Taking & $\begin{array}{l}\text { Perasaan } \\
\text { mampu }\end{array}$ \\
\hline Malu & $\begin{array}{l}\text { Time } \\
\text { Projection }\end{array}$ & Berani \\
\hline Bersedih hati & & Bahagia \\
\hline $\begin{array}{l}\text { Rasa } \\
\text { bersalah }\end{array}$ & & $\begin{array}{l}\text { Tidak merasa } \\
\text { bersalah }\end{array}$ \\
\hline Iri hati & & Rendah hati \\
\hline $\begin{array}{l}\text { Kurang } \\
\text { mandiri }\end{array}$ & & Mandiri \\
\hline
\end{tabular}

\section{METODE PENELITIAN}

Penelitian ini menggunakan metode penelitian single case experimental design. Desain eksperimen kasus tunggal (single-case experimental design) merupakan sebuah desain penelitian untuk mengevaluasi efek suatu perlakuan (intervensi) dengan kasus tunggal. Kasus tunggal dapat berupa beberapa subjek dalam satu kelompok atau subjek yang diteliti adalah tunggal $(\mathrm{N}=1)$. (Latipun, 2008).

Desain eksperimen kasus tunggal, baik sampel kelompok maupun $\mathrm{N}=1$, untuk kasus tertentu dianggap paling cocok untuk meneliti manusia, terutama apabila perilaku yang diamati tidak mungkin diambil rata-ratanya. Dalam beberapa kasus, rata-rata kelompok tidak dapat mencerminkan keadaan perilaku individu di dalam kelompok itu. Dengan kata lain, rata-rata kelompok tidak selalu mencerminkan keadaan individu-individu dalam kelompoknya.

Jadi di dalam penelitian ini, peneliti melakukan pengukuran yang sama dan berulang-ulang untuk mempelajari seberapa banyakkah perubahan yang terjadi pada variabel terikat (dependen) dari hari ke hari. Peneliti memilih desain ini karena penekanan dalam penelitian ini adalah "clinical setting" atau pada efek terapi. Alasan lain yang mendasari pemakaian desain ini ialah jumlah subjek penelitian yang sangat terbatas sehingga tidak dapat dilakukan komparasi antar kelompok. Suatu desain eksperimen kasus tunggal (single-case experimental design) diperlukan dan harus melakukan pengukuran keadaan awal sebagai fungsi pretes. Keadaan awal (baseline) merupakan pengukuran (beberapa) aspek dari perilaku subjek selama beberapa waktu sebelum perlakuan. Rentang waktu pengukuran untuk menetapkan baseline ini disebut fase keadaan awal (baseline phase). Fase keadaan awal ini memiliki fungsi deskriptif dan fungsi prediktif. Fungsi deskriptif (descriptive function) adalah fungsi untuk menggambarkan keberadaan level performansi (keadaan perilaku) subjek yang dieksperimen secara alamiah, tanpa adanya suatu perlakuan. Sedangkan fungsi prediktif atau disebut juga dengan fungsi projektif adalah fungsi untuk meramalkan level performansi (perilaku) subjek jika tidak ada intervensi.

Baseline berfungsi sebagai landasan pembanding untuk menilai keefektifan suatu perlakuan. Dalam penelitian ini peneliti menggunakan desain A-B-A withdrawal. Withdrawal design adalah meniadakan perlakuan untuk melihat apakah perlakuan tersebut efektif. Dalam desain eksperimental kasus tunggal, sebuah perilaku diukur (baseline), sebuah perlakuan diintroduksikan (intervensi), dan kemudian intervensi tersebut 
ditarik atau ditiadakan. Oleh karena perilaku tersebut diukur terus-menerus (pengukuran berulangulang), maka efek apa pun dari intervensi tersebut dapat dicatat. Adapun pengertian baseline (keadaan awal) ialah hasil pengukuran perilaku yang dilakukan sebelum diberikannya sebuah perlakuan (intervensi), yang memungkinkan dilakukannya pembandingan dan pengukuran terhadap efekefek intervensi.

Penelitian ini menggunakan teknik AB-A atau desain reversal, melalui tiga fase yaitu : Fase pertama adalah kondisi dasar subjek tanpa perlakuan (A), fase kedua adalah pemberian perlakuan (B), fase ketiga adalah pengulangan pengkondisian (A ; reversal). Desain A-B-A sangatlah mudah. Jika pemberian intervensi (variable independen) efektif, akan ada perubahan positif dalam kondisi yang diukur (variable dependen)

setelah intervensi diberikan, dan akan ada kembali ke tingkat dasar saat intervensi dihentikan (Latipun, 2008).

Peneliti melihat dan menganalisa secara berkala gejala-gejala yang ada pada subjek yang menggambarkan kondisi psychology well-being yang rendah seperti cemas, merasa bersalah, merasa depresi, perasaan tidak berdaya, malu, bersedih hati, perasaan rendah diri, iri hati, dan kurang mandiri akibat menderita epilepsi grandmal. Subjek penelitian adalah seorang perempuan berusia 21 tahun yang menderita epilepsi grandmal dan sedang menjalani pengobatan, berbadan gemuk dan tinggi, asal Jakarta, memiliki IQ rata-rata, bersedia menjadi subjek penelitian, diindikasikan memiliki kondisi psychology well-being yang rendah seperti cemas, merasa bersalah, merasa depresi, perasaan tidak berdaya, malu, bersedih hati, perasaan rendah diri, iri hati, dan kurang mandiri.

Berikut ini merupakan Pattern Matching Komponen Teoritik versus Temuan Studi Kasus :
Tabel 2 : Pattern Matching

\begin{tabular}{lrrr}
\hline $\begin{array}{l}\text { Gambaran } \\
\text { penderita } \\
\text { grandmal }\end{array}$ & $\begin{array}{r}\text { PWB } \\
\text { epilepsiada }\end{array}$ & $\begin{array}{l}\text { Ber- } \\
\text { da- } \\
\text { sar- } \\
\text { kan } \\
\text { teori }\end{array}$ & $\begin{array}{l}\text { Pa- } \\
\text { da } \\
\text { Sub- }\end{array}$ \\
\hline jemas & $\checkmark$ & $\checkmark$ \\
Merasa rendah diri & $\checkmark$ & $\checkmark$ \\
Merasa depresi & $\checkmark$ & \\
Perasaan tidak berdaya & $\checkmark$ & $\checkmark$ \\
Malu & $\checkmark$ & $\checkmark$ \\
Bersedih hati & $\checkmark$ & $\checkmark$ \\
Rasa bersalah & $\checkmark$ & $\checkmark$ \\
Iri hati & $\checkmark$ & $\checkmark$ \\
Kurang mandiri & $\checkmark$ & $\checkmark$ \\
\hline
\end{tabular}

Keterangan :

$\checkmark=$ Kesesuaian dengan temuan kasus

- $\quad=$ Ketidaksesuaian temuan kasus dengan teori

Berdasarkan tabel pattern matching maka menunjukkan sasaran perilaku yang ada pada subjek yaitu adanya rasa cemas, merasa rendah diri, perasaan tidak berdaya, malu, bersedih hati, memiliki rasa bersalah, iri hati dan kurang mandiri.

\section{HASIL DAN PEMBAHASAN}

Berdasarkan pattern matching maka menunjukkan sasaran perilaku yang ada pada subjek yaitu adanya rasa cemas, merasa rendah diri, perasaan tidak berdaya, malu, bersedih hati, memiliki rasa bersalah, iri hati dan kurang mandiri. Hingga perlahan subjek mampu mengubah kondisi psychological wellbeingnya, melalui teknik REBT : ceria, merasa percaya diri, gembira, perasaan mampu, berani, bahagia, tidak merasa bersalah, rendah hati, dan mandiri.

Dari hasil analisa, subjek sudah dapat menunjukan perkembangan yang baik dan perlahan-lahan sudah mampu melakukan halhal yang pada awalnya tidak dilakukan dan setelah mendapat intervensi berupa konseling dan terapi $\mathrm{K}$ dapat meningkatkan psychological well-beingnya, melalui terapi REBT. K sudah dapat memahami keadaankeadaan emosional yang membuat ia tidak dapat mengelola distress dan serangan epilepsinya kambuh, sehingga ia selalu berusaha untuk dapat memonitor dirinya.

Pelaksanaan penerapan teknik REBT dapat dikatakan efektif untuk mengubah emosi 
negatif dan pandangan negatif dalam upaya meningkatkan psychological well-being yang dialami klien yang menderita epilepsi jenis grandmal dengan IQ rata-rata. Pemilihan pendekatan REBT didasari oleh pertimbangan bahwa REBT akan dapat lebih banyak menggali pikiran-pikiran irasional yang mencetuskan gangguan mood dan emosi yang negatif pada penderita epilepsi grandmal termasuk masa depan klien. Sebagaimana dijelaskan oleh Ellis (dalam Corey, 1999) yang mengatakan bahwa pada hakikatnya manusia adalah korban dari pola pikirnya sendiri yang tidak rasional dan tidak benar sedangkan pada umumnya manusia memiliki kecenderungan untuk memelihara diri, berbahagia, berfikir dan mengatakan, mencintai, bergabung dengan orang lain serta tumbuh dan mengaktualisasikan diri. Hal ini sesuai dengan teori yang diungkapkan oleh Lumbantobing (1995) bahwa seorang penderita epilepsi dapat saja memiliki kepribadian yang normal. Hal ini mendukung bahwa terapi REBT dapat diterapkan pada penderita epilepsi namun dengan syarat IQ berada pada taraf rata-rata.

Berikut adalah hasil perkembangan Hasil Intervensi. Analisis ini dibuat untuk melihat perkembangan hasil intervensi pada sasaran perilaku yang diharapkan, berikut gambaran perkembangan hasil intervensi pada subjek.

Tabel 3 : Perkembangan Hasil Intervensi

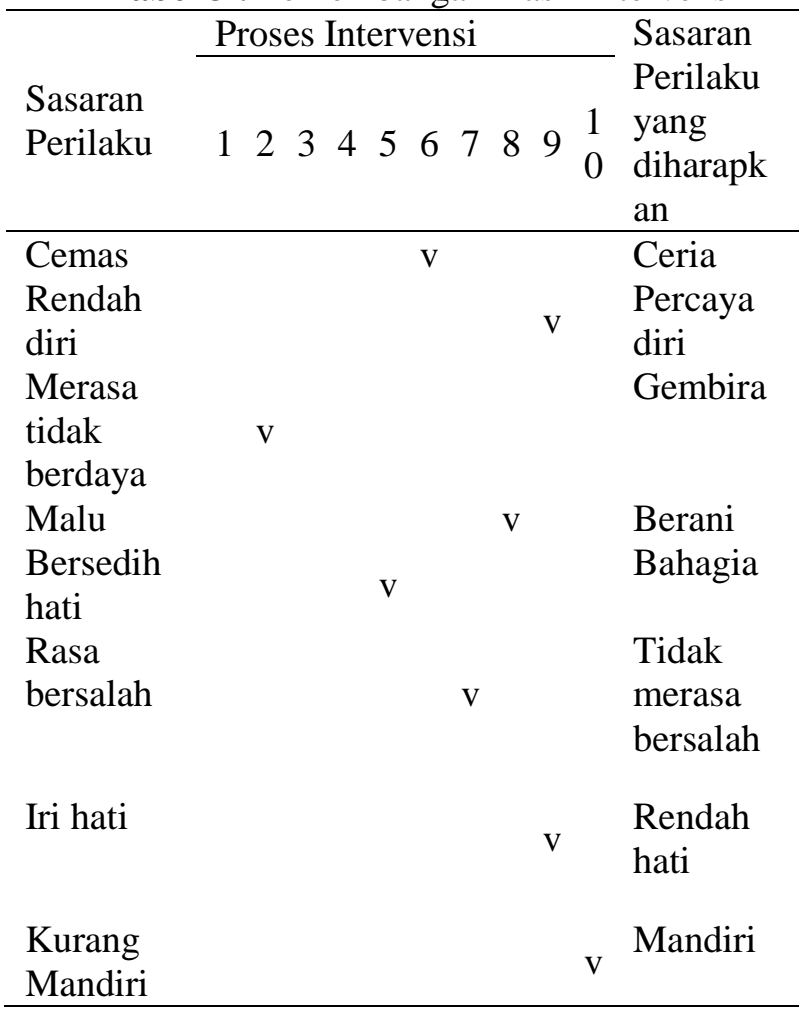

Berdasarkan data dari tabel perkembangan hasil terapi REBT di atas menunjukan adanya perubahan perilaku pada subjek setelah diberikan terapi, yaitu sebagai berikut : Perasaan tidak berdaya hilang pada pertemuan ke-2, seteleah diterapi $\mathrm{K}$ menjadi lebih bersyukur (gembira) walaupun ia sakit epilepsi namun ia masih memiliki kelebihankelebihan lain yang belum tentu dimiliki orang lain. Perasaan rendah diri hilang pada pertemuan ke-9, setelah dilakukan terapi $\mathrm{K}$ menjadi lebih percaya diri karena ia sudah dapat menilai sisi-sisi yang positif dalam dirinya dan lebih bersyukur. Perasaan Cemas hilang pada pertemuan ke-6, setelah diterapi ia dapat memperhitungkan tujuan hidupnya dengan memilih pekerjaan yang sesuai dengan kapasitasnya. Kemudian perasaan malu hilang pada pertemuan ke-8, setelah diterapi ia lebih berani untuk dapat berterus terang kepada orang lain. Perasaan sedih hilang pada pertemuan ke-5, seteleh diterapi $\mathrm{K}$ tetap merasa bahagia meskipun tidak mendapat banyak dukungan. Perasaan bersalah hilang pada pertemuan ke-7, setelah diterapi ia menjadi lebih bersyukur dan tidak lagi terusmenerus merasa bersalah. Perasaan iri hati hilang pada pertemuan ke-9, setelah diterapi K dapat menjadi lebih rendah hati terhadap orang lain. Terakhir adalah kurang mandiri hilang pada pertemuan ke-10, setelah diterapi $\mathrm{K}$ menjadi lebih mandiri tidak bergantung pada orang lain. Hasil akhir dari penerapan REBT, $\mathrm{K}$ menjadi lebih ceria, merasa percaya diri, gembira, perasaan mampu, berani, bahagia, tidak merasa bersalah, rendah hati, dan mandiri.

\section{SIMPULAN DAN SARAN}

Penerapan teknik pendekatan Rational
Emotive Behavior Therapy dapat meningkatkan psychological well-being subjek. Subjek menunjukkan perubahan perilaku dan pola pikir seperti : lebih ceria, merasa percaya diri, berkompetisi, memiliki perasaan mampu, berani, bahagia, tidak merasa bersalah, rendah hati, dan mandiri. Hasil ini diperkuat dengan hasil skala psychological well-being hasil pre-test yang rendah sebelum dilakukan intervensi dan setelah dilakukan intervensi maka perilaku yang diharapkan dapat tercapai, hal ini didukung oleh hasil post-test sudah menunjukan tingkat perilaku yang baik / 
tercapai. Berdasarkan hasil kesimpulan penelitian dan dari data yang telah diperoleh, peneliti menyarankan agar bagi peneliti yang tertarik untuk meneliti kembali untuk meningkatkan psychological well-being pada penderita epilepsi, maka perlu diketahui jenis epilepsi untuk mengetahui perbedaan intervensi yang akan diterapkan. Kemudian REBT hanya dapat diterapkan pada penderita epilepsi yang memiliki IQ minimal rata-rata.

Sedangkan saran bagi subjek penelitian adalah agar terus mengembangkan bakat dan minatnya secara lebih maksimal dan tidak berfokus pada kekurangan diri. Selain itu, subjek dapat mencari teman agar dapat mengungkapkan masalahnya supaya tidak mengalami distres.

\section{DAFTAR PUSTAKA}

Alwisol. (2004). Psikologi Kepribadian, Edisi Revisi. Malang : UMM Press.

American Psychiatric Association. (2000). Diagnostic and Statistical Manual of Mental Disorder, fourth edition, text revision. Washington DC : Task Force.

Carol D. Ryff. (1989). Happiness is Everything of is it?: Exploration meaning of psychological well-being. Journal of personality and social psychology. Volume 57, no. 6, 10651081

Davison, Gerald C, dkk. (2010). (Terjemahan oleh Noermalasari Fajar). Psikologi Abnormal. Edisi-9. Jakarta : Rajawali Press.

Diktat Kuliah. (1987). TES GRAFIS : Suatu Model Analisa Kepribadian. Bandung : Universitas Padjajaran.

Ikatan Psikologi Klinis. (2008). SPPK : Standar Pelayanan Psikologi Klinis. Jakarta : Himpunan Psikologi Indonesia.

Harsono. (2011). Buku Ajar Neurologi Klinis. Gajah Mada University Press : Yogyakarta

Hantoro, Rudi. (2013). Buku Pintar Keperawatan Epilepsi : Mengenal dan
Penanganannya. Penerbit Ilmu Cakrawala : Jakarta

Kangeaningsih, Sridjati. (2013). Yayasan Epilepsi Indonesia : Out of Shadow. IPB Press : Jakarta

Latipun. (2008). Psikologi Eksperimen. Malang : UMM Press - Universitas Muhamadiyah Malang.

Lumbantobing. (1994). Epilepsi (Ayan). Cetakan Keempat. Jakarta : Balai Penerbit Fakultas Kedokteran Universitas Indonesia.

Marnat, Gary Groth. (2010). (Terjemahan oleh Drs. Helly Prajitno Soetjipto, M.A). Handbook Of Psychological Assessment. Edisi Kelima. Yogyakarta : Pustaka Belajar

Palmer, Stephen. (2010). (Diterjemahkan oleh Introduction To Counseling and Psychotherapy: The Essential Guide). Konseling dan Psikoterapi. Pustaka Belajar : Jakarta

Ryff \& Burton. (2006). Know thyself and become what you are: a eudaimonic approach to psychological well-being. Journal of happiness stuedies. Vol. 9. Iss: 13. page 39 .

Primardi,

Aska. (2010). http://www.inaepsy.org/2010/09/odepen didikan.html?m=1

Shultz \& Shultz, Duane. (2010). Psychology and work today. New York : Prentice Hall 
